Arq. Bras. Med. Vet. Zootec., v.72, n.4, p.1381-1385, 2020

\title{
Aborto infeccioso por Neospora spp. em equino - relato de caso
}

\author{
[Neospora spp infectious abortion in the horse - case report] \\ J.I. Octaviano ${ }^{1}$, F.P. Carneiro $^{1}$, M.A. Redoan ${ }^{2}$, M.A. Alonso ${ }^{2}$, C.B. Fernandes ${ }^{1 *}$ \\ ${ }^{1}$ Faculdade de Medicina Veterinária e Zootecnia - Universidade de São Paulo - São Paulo, SP \\ ${ }^{2}$ Fazenda Santa Rita II - Piracaia, SP
}

\begin{abstract}
RESUMO
O abortamento na espécie equina é responsável por grandes perdas econômicas e, entre as possíveis causas, está a neosporose, uma enfermidade que nem sempre é investigada como provável diagnóstico. Assim, o objetivo deste trabalho foi relatar um caso de aborto equino aos 129 dias de gestação, resultante da infecção por Neospora spp.. Amostras sanguíneas da égua e do feto abortado foram enviadas para um laboratório especializado. À necrópsia, constatou-se edema gelatinoso e hemorrágico em subcutâneo, fígado ictérico e friável com autólise de alguns órgãos, como baço, rins e glândulas adrenais. Fragmentos dos órgãos coletados na necrópsia foram submetidos à histopatologia e à pesquisa de agentes infecciosos, em que se identificou hepatite e epicardite não purulentas e onfalite purulenta, bem como exame positivo para Neospora spp. pela técnica de reação em cadeia da polimerase (PCR) convencional e Nested. O soro sanguíneo obtido da égua foi submetido à pesquisa de Neospora spp. pela técnica de imunofluorescência indireta, de herpesvírus por soroneutralização em cultura de células e de Leptospira sp. por PCR, todas com resultados negativos. Dessa forma, é importante considerar a neosporose como diagnóstico diferencial em casos de abortamento e natimortalidade, uma vez que a presença de cães nas propriedades é extremamente comum, representando uma importante fonte de infecção.
\end{abstract}

Palavras-chave: égua, neosporose, aborto, infeccioso, feto

\begin{abstract}
Abortion in the equine species is responsible for major economic losses, and among the possible causes is neosporosis, a disease that is not always investigated as a probable diagnosis. Thus, the objective of this study was to report an abortion at 129 days of gestation resulting from Neospora spp. Blood samples from the mare and the aborted fetus were sent to a specialized laboratory. Under necropsy, gelatinous and hemorrhagic edema was detected in subcutaneous tissue, friable and jaundiced liver with autolysis in spleen, kidneys and adrenal glands. Fragments of the organs collected at necropsy were submitted to histopathology and infectious agent tests, which identified non-purulent hepatitis and epicarditis and purulent omphalitis. Also, a positive result for Neospora spp. by the conventional and nested Polymerase Chain Reaction (PCR) technique. Blood serum obtained from the mare was subjected to analyses to Neospora spp. by indirect immunofluorescence technique, herpesvirus by serum neutralization in cell culture and Leptospira sp. by PCR, all with negative results. Thus, it is important to consider neosporosis as a differential diagnosis in cases of abortion and stillbirth, since the presence of dogs in the properties is extremely common and represent an important source of infection.
\end{abstract}

Keywords: mare, neosporosis, abortion, infectious, fetus

Recebido em 25 de outubro de 2019

Aceito em 11 de fevereiro de 2020

*Autor para correspondência (corresponding author)

E-mail: fernandescb@usp.br 


\section{INTRODUÇÃO}

A ocorrência de abortamentos e de natimortalidades, de causas infecciosas ou não, leva à expressiva perda econômica na indústria equina. Dentre as causas infecciosas mais comuns, destacam-se o herpesvírus equino HVE 1 e as infeccções bacterianas por Escherichia coli e Leptospira sp. Entretanto, existem outros agentes etiológicos já identificados, mas pouco investigados que acarretam perdas gestacionais, entre eles a Neospora sp. (Veronesi et al., 2008). A neosporose foi descrita pela primeira vez na década de 80 , na Noruega, quando uma ninhada de cães apresentou um quadro clínico de encefalomielite, que evoluiu para paralisia ascendente dos membros posteriores. Em 1988, o agente etiológico da neosporose foi identificado e denominado Neospora caninum (Cerqueira-Cézar et al., 2017).

A Neospora spp. é um parasita intracelular obrigatório, pertencente ao reino Protozoa, filo Apicomplexa, família Sarcocytida. Duas espécies dos protozoários são responsáveis por infecções em equinos, a Neospora caninum e a Neospora hughesi, sendo a infecção por $N$. caninum associada a problemas reprodutivos e doença neonatal, e a infecção por $N$. hughesi a distúrbios neurológicos (Veronesi et al., 2008; CerqueiraCézar et al., 2017).

Por envolver mais de um hospedeiro, o ciclo biológico da Neospora caninum é classificado como heteroxeno. Os canídeos compõem o ciclo biológico como hospedeiros definitivos, e os herbívoros atuam como hospedeiros intermediários (Dubey et al., 2007).

A infecção causada pelo $N$. caninum é reconhecida mundialmente e acomete animais domésticos, como bovinos, ovinos, caprinos, cervídeos, cães e equinos (Dubey, 2003). Em equinos, a enfermidade está relacionada a abortamentos, doenças neonatais e distúrbios reprodutivos (Locatelli-Dittrich et al., 2006). Em bovinos, a transmissão transplacentária tem papel de destaque na perpetuação desse agente na população, provavelmente pelas características placentárias das vacas permitirem uma maior efetividade do parasito (Dubey et al., 2007).
A transmissão vertical de Neospora spp. da égua gestante para o feto está envolvida na manutenção do protozoário na população equina, considerando-se que a infecção congênita pode resultar no nascimento de animais persistentemente infectados (Locatelli-Dittrich et al., 2006). Um aspecto a ser ressaltado é que o contato de equinos com cães e/ou bovinos é apontado como fator de risco para a infecção por Neospora spp., indicando que a transmissão horizontal também pode ser importante nessa espécie (Moura et al., 2013).

No Brasil, a prevalência de anticorpos antiNeospora spp. entre equinos foi estimada em 25,7\% (RIFI) em Santa Catarina (Abreu et al., 2014) e em 57,6\% (RIFI) em São Paulo (Stelmann et al., 2011), evidenciando que o diagnóstico diferencial para essa afecção deve ser considerado em anormalidades reprodutivas envolvendo éguas gestantes

\section{CASUÍSTICA}

Uma égua da raça Mangalarga Paulista de sete anos de idade, nulípara, apresentou um abortamento espontâneo aos 129 dias de gestação, em uma propriedade localizada em Piracaia, no estado de São Paulo (latitude: 2303'14" sul; longitude: 46 $21^{\prime} 29^{\prime \prime}$ oeste; altitude: 792 metros).

Foi relatado na anamnese que o animal apresentou quadro clínico de babesiose dois meses antes da data do abortamento, o que levou a uma diminuição significativa no ECC (escore de condição corporal) na ocasião. Além disso, nenhuma outra afecção ou sintomatologia foi relatada. Imediatamente após o abortamento, o feto inteiro e os anexos fetais foram coletados e refrigerados a $5^{\circ} \mathrm{C}$ (Fig. 1). Foi realizada também a coleta de uma amostra de sangue da égua por venopunção jugular em tubos sem anticoagulante (Vacuplast $^{\circledR}$ ). Após a coleta, o tubo contendo a amostra foi deixado em repouso por 30 minutos, em temperatura ambiente, e centrifugado por 10 minutos para a formação do coágulo e obtenção do soro sanguíneo. Uma vez separado, o soro foi aliquotado em criotubos de $2 \mathrm{~mL}$, os quais foram mantidos sob refrigeração $\left(5^{\circ} \mathrm{C}\right)$ para o envio ao laboratório do Instituto Biológico, localizado na cidade de São Paulo - SP. 


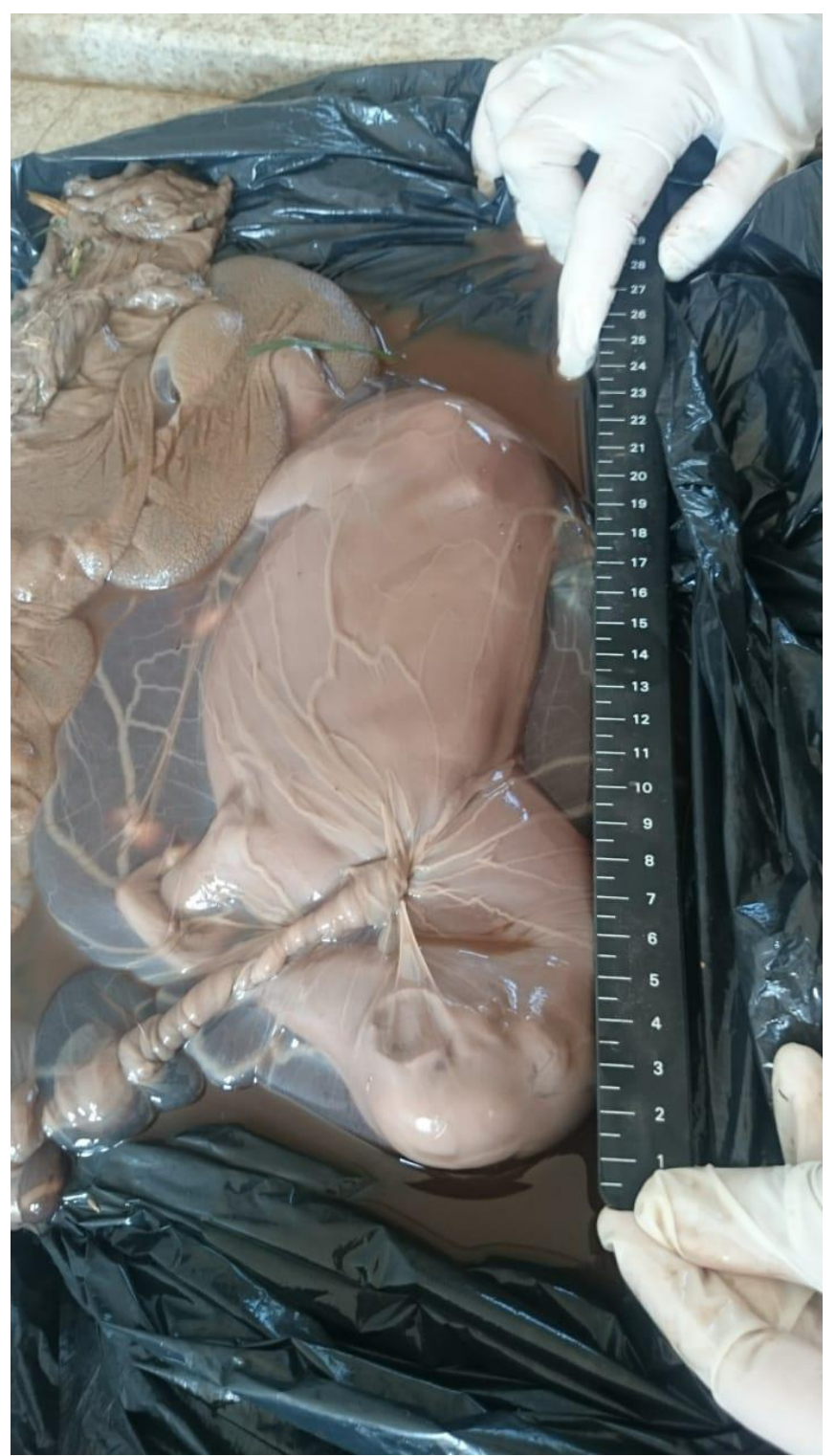

Figura 1. Aborto equino: feto e anexos fetais aos 129 dias de gestação, imediatamente após o abortamento, de uma égua Mangalarga.

\begin{abstract}
À necropsia, o feto apresentou macroscopicamente edema gelatinoso e hemorrágico em subcutâneo, fígado ictérico e friável, além da autólise de alguns órgãos, como baço, rins e glândulas adrenais. Fragmentos dos órgãos foram coletados e acondicionados em formaldeído $10 \%$ para análise histopatológica, a qual revelou hepatite e epicardite não purulentas e onfalite purulenta, confirmando o abortamento infeccioso.
\end{abstract}

As amostras coletadas foram também submetidas à pesquisa de agentes infecciosos responsáveis por abortamento na espécie equina, tais como brucelose, leptospirose, micoplasmose, protozoários da família Sarcocystidae (Neospora spp., Sarcocystis neurona, Toxoplasma gondii), herpesvírus (HVE-1) e vírus da arterite equina, utilizando-se a técnica de reação em cadeia da polimerase (PCR) convencional e Nested. Como resultado, obteve-se positividade apenas para Neospora spp.

Com a amostra sérica da égua, foram realizadas as técnicas de imunofluorescência indireta para Neospora spp., com ponto de corte 1:50, 
soroneutralização em cultura de células para diagnóstico de herpesvírus e PCR para Leptospira sp., todos com resultados negativos.

\section{DISCUSSÃO}

O diagnóstico da neosporose pode ser realizado por métodos sorológicos e parasitológicos empregados em amostras, como sangue, anexos fetais e feto. Entre os testes sorológicos, estão a imunofluorescência indireta, o ensaio imunoenzimático (ELISA), a soroaglutinação e o Western Blot, sendo a técnica de imunofluorescência indireta a mais utilizada. Para o diagnóstico parasitológico, são empregadas a histopatologia, a imuno-histoquímica e a PCR (Hemphill et al., 2000).

No presente relato de caso, o teste sorológico realizado na égua foi a imunofluorescência indireta, considerada um teste padrão na pesquisa de anticorpos e que apresentou a titulação 1:50, ou seja, negativa para Neospora spp. No entanto, o diagnóstico parasitológico realizado nos tecidos fetais confirmou a presença do agente Neospora spp., por meio da técnica de PCR, que assegura o enriquecimento de um fragmento específico de DNA mediante a sua duplicação em modo exponencial, apresentando alta sensibilidade e especificidade, e, dessa forma, determinando o diagnóstico do abortamento, independentemente da sorologia apresentada pela égua. Apesar de o resultado produzido pelo Instituto Biológico não identificar a espécie de Neospora das amostras analisadas, acredita-se tratar-se de $N$. caninum devido à relação com problemas reprodutivos e doença neonatal (Veronesi et al., 2008; CerqueiraCézar et al., 2017).

Hoffmann Kormann et al. (2008), ao avaliarem a soroprevalência e a dinâmica de anticorpos antiNeospora spp. em éguas Puro Sangue Inglês entre o oitavo e $11^{\circ}$ meses de gestação, pela técnica de imunofluorescência indireta e utilizando dois pontos de corte distintos, 1:50 e 1:100, constataram uma acentuada variação dos níveis séricos de anticorpos anti-Neospora spp. Na titulação 1:50, uma maior soroprevalência (86\%) ocorreu no oitavo mês de gestação, enquanto na titulação 1:100, a maior soroprevalência (64\%) obtida foi no $11^{\circ}$ mês de gestação. Além disso, foi demonstrada também uma alta variabilidade entre as respostas individuais.
$\mathrm{Na}$ tentativa de se associar a infecção por Neospora spp. com taxas de abortamentos e natimortalidade, foi detectado DNA do protozoário $N$. caninum por meio de PCR em três abortos (antes de três meses de gestação) e em três potros natimortos, em um total de 26 perdas gestacionais estudadas na espécie equina. Nesse estudo de Veronesi et al. (2008), não foram encontradas evidências histológicas de lesões pelo protozoário em cérebro dos fetos, e nenhuma das éguas demonstrou títulos de anticorpos contra Neospora sp. em imunofluorescência. Os resultados foram semelhantes aos obtidos no presente relato de caso, em que o diagnóstico do abortamento foi embasado na detecção do DNA, a despeito da sorologia negativa.

Apesar das semelhanças com o relato de Veronesi et al. (2008), os achados de necropsia do presente relato, com lise celular e tecidual e importantes alterações inflamatórias em fígado, epicárdio e ônfalo, caracterizam lesões histopatológicas significativas no processo infeccioso apresentado. Assim como em relatos anteriores em que sorologias positivas para Neospora spp. foram obtidas em potros neonatos pré-ingestão de colostro, os achados deste estudo corroboram a hipótese de que haja uma transmissão vertical transplacentária de Neospora spp., uma vez que o DNA foi obtido em tecido fetal.

Dessa forma, apesar de a Neosporose não ser considerada uma das principais enfermidades relacionadas a perdas gestacionais na espécie equina, este relato de caso vem para enfatizar a necessidade de inclusão desse agente etiológico no rol de exames a serem realizados nos casos de abortamento e natimortalidade em equinos, visto que a presença de cães e a criação conjunta de diferentes espécies em propriedades rurais brasileiras são extremamente comuns, o que pode contribuir para a disseminação da afecção.

Com o incremento dessa avaliação, não somente por meio de sorologia, mas também por meio da busca e identificação biomolecular do agente no aborto, pode-se, no futuro, evidenciar um acréscimo na identificação desse agente nas casuísticas de perdas gestacionais em criatórios nacionais. 


\section{AGRADECIMENTOS}

À Fundação de Apoio à Pesquisa do Estado de São Paulo (Fapesp No 2017/05425-0), à Coordenação de Aperfeiçoamento de Pessoal de Nível Superior - Brasil (Capes) - Código de Financiamento 001.

\section{REFERÊNCIAS}

ABREU, R.A.; WEISS, R.R.; THOMAZSOCCOL, V. et al. Association of antibodies against Neospora caninum in mares with reproductive problems and presence of seropositive dogs as a risk factor. Vet. Parasitol., v.202, p.128-131, 2014.

CERQUEIRA-CÉZAR， C.K.; CALEROBERNAL, R.; DUBEY, J.P. et al. All about neosporosis in Brazil. Braz. J. Vet. Parasitol., v.26, p.253-279, 2017.

DUBEY, J.P. Review of Neospora caninum and neosporosis in animals. Korean J. Parasitol., v.41, p.1-16, 2003.

DUBEY, J.P.; SCHARES, G.; ORTEGA-MORA, L.M. Epidemiology and control of neosporosis and neospora caninum. Clin. Microbiol. Rev., v.20, p.323-367, 2007.

HEMPHILL, A.; GOTTSTEIN, B.; CONRATHS, F.J. et al. A European perspective on Neospora caninum. Int. J. Parasitol., v.30, p.877-924, 2000.
HOFFMANN KORMANN, D.C.S.; LOCATELLIDITTRICH, R.; RICHARTZ, R.R.T.B. et al. Soroprevalência e cinética mensal de anticorpos anti-Neospora sp. em éguas gestantes. Rev. Bras. Parasitol. Vet., v.17, p.335-338, 2008.

LOCATELLI-DITTRICH, R.; DITTRICH, J.R.; RICHARTZ, R.R.T.B. et al. Investigation of neospora sp. and toxoplasma gondii antibodies in mares and in precolostral foals from Parana State, Southern Brazil. Vet. Parasitol., v.135, p.215221, 2006.

LOCATELLI-DITTRICH, R.; HOFFMANN, D.C.S.; DITTRICH，J.R. Neosporose quina revisão. Arch. Vet. Sci., v.11, p.1-10, 2006.

MOURA, A.B.; SILVA, M.O.; FARIAS, J.A. et al. Neospora spp. antibodies in horses from two geographical regions of the state of Santa Catarina, Brazil. Vet. Bras. Parasitol. Vet., v.22, p.597-601, 2013.

STELMANN, U.J.P.; ULMANN, L.S.; LANGONI, H. et al. Equine neosporosis: search for antibodies in cerebrospinal anda sera from animals with history of ataxia. Rev. Bras. Med. Vet., v.33, p.99-102, 2011.

VERONESI, F.; DIAFERIA, M.; MANDARA, M.T. et al. Neospora spp. infection associated with equine abortion and/or stillbirth rate. Vet. Res. Commun., v.32, Suppl.1, p.223-226, 2008. 